\title{
TEORI BELAJAR ROBERT M. GAGNE DAN IMPLIKASINYA PADA PENTINGNYA PUSAT SUMBER BELAJAR
}

\author{
Oleh: Bambang Warsita *
}

\section{Abstrak}

Teori belajar model nine instructional events Robert. M. Gagne ini membantu para guru, para perancang pembelajaran dan para pengembang program pembelajaran untuk memahami proses belajar yang terjadi di dalam diri peserta didik sehingga dapat mempengaruhi, memperlancar atau menghambat proses belajar peserta didik. Selain itu, model ini membantu kita untuk melakukan intervensi dengan mengembangkan Pusat Sumber Belajar (PSB), sehingga dapat meningkatkan efektivitas dan efisiensi kegiatan pembelajaran melalui pengembangan sistem instruksional. Dalam melaksanakan fungsi pengembangan sistem instruksional (instructional development), PSB menyediakan sumber-sumber belajar yang dapat dimanfaatkan oleh guru dan peserta didik.

Kata kunci: belajar, teori belajar, pembelajaran, sumber belajar dan Pusat Sumber Belajar (PSB).

\section{A. LATAR BELAKANG}

Belajar merupan kegiatan orang sehari-hari. Bahkan kemampuan orang untuk belajar ini merupakan salah satu ciri penting yang membedakan manusia dengan makhluk yang lain. Dengan demikian kemampuan belajar yang dimiliki manusia ini merupakan bekal yang sangat penting. Berdasarkan kemampuan itu umat manusia telah berkembang selama berabad-abad yang lalu dan tetap terbuka kesempatan luas baginya untuk memperkaya diri dan mencapai taraf kebudayaan yang lebih tinggi (Winkel, 2005).

Belajar adalah suatu proses yang kompleks dan terjadi pada semua orang serta berlangsung seumur hidup. Karena kompleksnya masalah belajar, banyak sekali teori yang berusaha menjelaskan bagaimana proses belajar itu terjadi. Setiap teori memiliki konsep atau prinsip-prinsip sendiri tentang belajar dan mempengaruhi bentuk sumber belajar yang digunakan dalam kegiatan pembelajaran.

Setiap teori belajar memiliki titik fokus yang menjadi pusat perhatian. Misalnya ada yang lebih mementingkan pada proses belajar, ada yang mementingkan pada hasil belajar, ada yang menekankan pada isi atau apa yang dilelajari, ada yang lebih mementingkan sistem informasi yang diolah dalam proses pembelajaran, dan ada yang menekankan pada pembentukan atau mengkonstruksi (membangun) pengetahuan, sikap atau keterampilannya sendiri.

Mengingat kegiatan pembelajaran tidak dapat dilakukan sembarangan, tetapi harus berlandaskan pada teori-teori dan prinsipprinsip belajar tertentu agar bisa bertindak

*) Drs. Bambang Warsita adalah staf Pusat Teknologi Informasi dan komunikasi Pendidikan (PUSTEKKOM)-Departemen Pendidikan Nasional. 
secara tepat. Artinya teori-teori dan prinsipprinsip belajar ini diharapkan dapat membimbing dan mengarahkan dalam merancang dan melaksanakan kegiatan pembelajaran. Walaupun teori belajar tidak dapat diharapkan menentukan langkah demi langkah dalam kegiatan pembelajaran, namun akan dapat memberi arah prioritas dalam kegiatan pembelajaran (Dimyati \& Mudjiono, 2002:41-42). Oleh karena itu, para guru, para perancang pembelajaran dan para pengembang program pembelajaran yang profesional perlu memilih teori belajar yang tepat untuk diterapkan dalam desain instruksional yang akan dikembangkan (instructional development and design).

Salah satu teori dan prinsip belajar yang penting untuk diterapkan atau diaplikasikan dalam kegiatan pembelajaran adalah teori Robert M. Gagne, yang sering dikenal dengan 9 peristiwa pembelajaran atau model nine instructional events Gagne. Pusat Sumber Belajar (PSB) dalam melaksanakan fungsinya, yaitu pengembangan sistem instruksional (instructional development), PSB menyediakan sumber-sumber belajar (learning resources) yang dapat dan harus dimanfaatkan oleh instruktur/pendidik dan peserta didik. Bahan-bahan instruksional itu meliputi bahan belajar cetak dan non cetak, serta sumber manusiawi dalam membentuk pengembangan sistem instruksional untuk meningkatkan efektivitas dan efisiensi kegiatan pembelajaran.

Pentingnya sumber belajar dalam kegiatan pembelajaran tak bisa dipungkiri lagi. Akan tetapi, sumber-sumber belajar yang ada di satuan pendidikan selama ini, umumnya belum dimanfaatkan dan dikelola secara maksimal untuk tujuan pembelajaran. Padahal, berbagai sumber belajar tersebut hanya akan berdaya guna jika sudah dikelola dan difungsikan secara maksimal dan terorganisir. Oleh karena itu, sudah saatnya setiap satuan pendidikan berupaya untuk mengoptimalkan pengelolaan berbagai sumber belajar secara sistematis dan melembaga dalam bentuk Pusat Sumber Belajar (PSB) atau Learning Resources Centre (LRC). Permasalahannya adalah bagaimana prinsip-prinsip belajar yang ditarik berdasarkan teori belajar Robert M. Gagne? Bagaimana implikasi teori belajar Robert M.
Gagne dengan pentingnya Pusat Sumber Belajar (PSB)?

\section{B. TEORI BELAJAR ROBERT M. GAGNE}

Robert. M. Gagne dalam bukunya: The Conditioning of Learning mengemukakan bahwa: Learning is a change in human disposition or capacity, wich persists over a period time, and wich is not simply ascribable to process of growth. Belajar adalah perubahan yang terjadi dalam kemampuan manusia setelah belajar secara terus menerus, bukan hanya disebabkan oleh proses pertumbuhan saja. Gagne berkeyakinan bahwa belajar dipengaruhi oleh faktor dari luar diri dan faktor dalam diri dan keduanya saling berinteraksi.

Gagne (1972) mendefinisikan belajar adalah mekanisme di mana seseorang menjadi anggota masyarakat yang berfungsi secara kompleks. Kompetensi itu meliputi, skill, pengetahuan, attitude (perilaku), dan nilainilai yang diperlukan oleh manusia, sehingga belajar adalah hasil dalam berbagai macam tingkah laku yang selanjutnya disebut kapasitas. Kemampuan-kemampuan tersebut diperoleh peserta didik dari: (1) stimulus dan lingkungan, dan (2) proses kognitif.

Menurut Gagne (1977), belajar merupakan seperangkat proses yang bersifat internal bagi setiap individu sebagai hasil transformasi rangsangan yang berasal dari peristiwa eksternal di lingkungan individu yang bersangkutan (kondisi). Agar kondisi eksternal itu lebih bermakna sebaiknya diorganisasikan dalam urutan peristiwa pembelajaran (metode atau perlakuan). Selain itu, dalam usaha mengatur kondisi eksternal diperlukan berbagai rangsangan yang dapat diterima oleh panca indera, yang dikenal dengan nama media dan sumber belajar (Miarso, 2004:245).

Pembelajaran menurut Gagne hendaknya mampu menimbulkan peristiwa belajar dan proses kognitif. Peristiwa pembelajaran (instructional events) adalah peristiwa dengan urutan sebagai berikut: (1) menimbulkan minat dan memusatkan perhatian agar peserta didik siap menerima pelajaran, (2) 
menyampaikan tujuan pembelajaran agar peserta didik tahu apa yang diharapkan dalam belajar itu, (3) mengingat kembali konsep/ prinsip yang telah dipelajari sebelumnya yang merupakan prasyarat, (4) menyampaikan materi pembelajaran, (5) memberikan bimbingan atau pedoman untuk belajar, (6) membangkitkan timbulnya unjuk kerja (merespon) peserta didik, (7) memberikan umpan balik tentang kebenaran pelaksanaan tugas (penguatan), (8) mengukur/ mengevaluasi hasil belajar, dan (9) memperkuat retensi dan transfer belajar (Miarso, 2004:245-246).

Teori Robert M. Gagne, yang disebut dengan sembilan peristiwa pembelajaran (model nine instructional events Gagne) adalah peristiwa yang dirancang oleh pendidik (eksternal) untuk membantu proses belajar dalam diri peserta didik (internal). Bentuk seutuhnya dari setiap peristiwa tidak harus ditetapkan untuk semua mata pelajaran. Guru perlu mengembangkan sendiri sesuai dengan

Tabel 1. Bagan sembilan peristiwa pembelajaran (Suciati \& Irawan, 2001:62-65)

\begin{tabular}{|c|c|c|}
\hline No. & Peristiwa Pembelajaran & Penjelasan \\
\hline 1. & $\begin{array}{l}\text { Menimbulkan minat dan } \\
\text { memusatkan } \\
\text { perhatian peserta didik }\end{array}$ & $\begin{array}{l}\text { Peserta didik tidak selalu siap dan terfokus perhatiannya pada awal } \\
\text { pembelajaran. Guru perlu menimbulkan minat dan perhatian peserta didik } \\
\text { melalui penyampaian sesuatu yang baru, aneh, kontradiksi atau kompleks. }\end{array}$ \\
\hline 2. & $\begin{array}{l}\text { Menyampaikan tujuan } \\
\text { pembelajaran }\end{array}$ & $\begin{array}{l}\text { Hal ini dilakukan agar peserta didik tidak menebak-nebak apa yang } \\
\text { diharapkan dari dirinya oleh guru. Mereka perlu mengetahui unjuk kerja apa } \\
\text { yang akan digunakan sebagai indikator penguasaan pengetahuan/- } \\
\text { keterampilan. }\end{array}$ \\
\hline 3. & $\begin{array}{l}\text { Mengingat kembali konsep/prinsip } \\
\text { yang telah dipelajari yang } \\
\text { merupakan prasyarat }\end{array}$ & $\begin{array}{l}\text { Banyak pengetahuan baru yang merupakan kombinasi dari konsep, prinsip } \\
\text { atau informasi yang sebelumnya telah dipelajari, untuk memudahkan } \\
\text { mempelajari materi baru. }\end{array}$ \\
\hline 4. & $\begin{array}{l}\text { Menyampaikan materi } \\
\text { pembelajaran }\end{array}$ & $\begin{array}{l}\text { Dalam menjelaskan materi pembelajaran, menggunakan contoh, penekanan } \\
\text { untuk menunjukkan perbedaan atau bagian yang penting, baik secara verbal } \\
\text { maupun menggunakan feature tertentu (warna, huruf miring, garis bawahi, } \\
\text { dsb). }\end{array}$ \\
\hline 5. & $\begin{array}{l}\text { Memberikan bimbingan atau } \\
\text { pedoman untuk belajar }\end{array}$ & $\begin{array}{l}\text { Bimbingan diberikan melalui pertanyaan-pertanyaan yang membimbing } \\
\text { proses/alur pikir peserta didik. Perlu diperhatikan agar bimbingan tidak } \\
\text { diberikan secara berlebihan. }\end{array}$ \\
\hline 6. & $\begin{array}{l}\text { Memperoleh unjuk kerja } \\
\text { (merespon) peserta didik }\end{array}$ & $\begin{array}{l}\text { Peserta didik diminta untuk menun-jukkan apa yang telah dipelajari, baik } \\
\text { untuk meyakinkan guru maupun dirinya sendiri. }\end{array}$ \\
\hline 7. & $\begin{array}{l}\text { Memberikan umpan balik tentang } \\
\text { kebenaran pelaksanaan tugas } \\
\text { (pengu-atan) }\end{array}$ & $\begin{array}{l}\text { Umpan balik perlu diberikan untuk membantu peserta didik mengetahui } \\
\text { tentang sejauh mana kebenaran atau unjuk kerja yang dihasilkannya. }\end{array}$ \\
\hline 8. & $\begin{array}{l}\text { Mengukur/mengevaluasi hasil } \\
\text { belajar. }\end{array}$ & $\begin{array}{l}\text { Pengukuran hasil belajar dapat dilakukan melalui tes maupun tugas } \\
\text { (misalnya kerja laboratorium). Perlu dipertimbangkan validitas dan reliabilitas } \\
\text { tes yang diberikan dan hasil observasi guru. }\end{array}$ \\
\hline 9. & $\begin{array}{l}\text { Memperkuat retensi dan transfer } \\
\text { belajar }\end{array}$ & $\begin{array}{l}\text { Retensi dapat ditingkatkan melalui latihan berkali-kali menggunakan prinsip } \\
\text { yang dipelajari dalam konteks yang berbeda. Kondisi/situasi pada saat } \\
\text { transfer belajar diharapkan terjadi, harus berbeda. Memecahkan masalah } \\
\text { dalam suasana di kelas akan sangat berbeda dengan suasana riil yang } \\
\text { mengandung resiko. }\end{array}$ \\
\hline
\end{tabular}


kompetensi dasar untuk dapat membantu proses belajar peserta didik (Suciati \& Irawan, 2001:62). Sedangkan urutannya tidak harus seperti dalam tabel di bawah ini, demikian pula tidak semua peristiwa harus digunakan dalam satu kegiatan pembelajaran.

Menurut Gagne, belajar memberi kontribusi terhadap adaptasi yang diperlukan untuk mengembangkan proses yang logis, sehingga perkembangan tingkah laku (behavior) adalah hasil dari efek belajar yang kumulatif (Gagne, 1968). Lebih lanjut ia menjelaskan bahwa belajar itu bukan proses tunggal. Belajar menurut Gagne tidak dapat didefinisikan dengan mudah karena belajar bersifat kompleks.

Gagne (1985) mengkaji masalah belajar yang kompleks dan menyimpulkan bahwa informasi dasar atau keterampilan sederhana yang dipelajari mempengaruhi terjadinya belajar yang lebih rumit. Menurut Gagne ada lima kategori kemampuan belajar, yaitu: (1) keterampilan intelektual atau kemampuan seseorang untuk berinteraksi dengan lingkungannya melalui penggunaan lambang. Keterampilan itu meliputi: (a) asosiasi dan mata rantai (menghubungkan suatu lambang dengan suatu fakta atau kejadian, (b) diskriminasi (membedakan suatu lambang dengan lambang lain), (c) konsep (mendefinisikan suatu pengertian atau prosedur), (d) kaidah (mengkombinasikan beberapa konsep dengan suatu cara), (e) kaidah lebih tinggi (menggunakan berbagai kaidah dalam memecahkan masalah; (2) strategi/siasat kognitif yaitu keterampilan peserta didik untuk mengatur proses internal perhatian, belajar, ingatan, dan pikiran; (3) informasi verbal yaitu kemampuan untuk mengenal dan menyimpan nama atau istilah, fakta, dan serangkaian fakta yang merupakan kumpulan pengetahuan; (4) keterampilan motorik yaitu keterampilan mengorganisasikan gerakan sehingga terbentuk keutuhan gerakan yang mulus, teratur, dan tepat waktu; dan (5) sikap yaitu

Tabel 2. Bagan lima kategori kemampuan belajar

\begin{tabular}{|c|c|c|c|}
\hline No. & $\begin{array}{l}\text { Jenis hasil } \\
\text { belajar }\end{array}$ & $\begin{array}{c}\text { Deskripsi } \\
\text { kemampuan }\end{array}$ & Contoh \\
\hline 1. & $\begin{array}{l}\text { Kemampuan } \\
\text { intelektual }\end{array}$ & $\begin{array}{l}\text { Menerapkan konsep dan peraturan } \\
\text { untuk mengatasi masalah dan ide- } \\
\text { ide untuk menghasilkan produk. }\end{array}$ & $\begin{array}{l}\text { Merancang dan mengkode program } \\
\text { komputer yang bisa memenuhi } \\
\text { keinginan }\end{array}$ \\
\hline 2. & Strategi kognitif & $\begin{array}{l}\text { Mengelola pikiran dan proses } \\
\text { belajar seseorang }\end{array}$ & $\begin{array}{l}\text { Secara selektif me-milih menggunakan } \\
\text { tiga strategi yang berbeda untuk men- } \\
\text { diagnosa kerusakan mesin. }\end{array}$ \\
\hline 3. & Informasi verbal & $\begin{array}{l}\text { Menyebutkan, menceritakan, atau } \\
\text { meng-gambarkan informasi yang } \\
\text { telah tersimpan sebelumnya. }\end{array}$ & $\begin{array}{l}\text { Menyebutkan tiga alasan prosedur } \\
\text { keselamatan perusahaan. }\end{array}$ \\
\hline 4. & $\begin{array}{l}\text { Kemampuan } \\
\text { keterampilan } \\
\text { motorik (skill) }\end{array}$ & $\begin{array}{l}\text { Melaksanakan suatu tindakan } \\
\text { dengan tepat dan cepat. }\end{array}$ & $\begin{array}{l}\text { Menembak benda kecil bergerak } \\
\text { dengan senapan secara tepat dan } \\
\text { konsisten. }\end{array}$ \\
\hline 5. & Sikap & Menentukan tindakan pribadi & $\begin{array}{l}\text { Memilih dan meres-pon semua surat } \\
\text { yang masuk dalam waktu } 24 \text { jam. }\end{array}$ \\
\hline
\end{tabular}


keadaan dalam diri peserta didik yang mempengaruhi (bertindak sebagai moderator atas) pilihan untuk bertindak. Sikap ini meliputi komponen afektif (emosional), aspek kognitif, dan unjuk perbuatan (Miarso, 2004:551). Untuk lebih jelasnya, kelima kemampuan belajar ini disajikan dalam tabel berikut!

Selanjutnya, Gagne mengatakan bahwa untuk dapat memperoleh dan menguasai kelima kategori kapabilitas tersebut dengan sebaik-baiknya ada sejumlah kondisi yang perlu diperhatikan oleh para pendidik. Ada kondisi belajar internal, yang timbul dari memori peserta didik sebagai hasil dari belajar sebelumnya, dan ada sejumlah kondisi eksternal ditinjau dari peserta didik. Kondisi eksternal ini bila diatur dan dikelola dengan baik merupakan usaha untuk membelajarkan. Misalnya pemanfaatan atau penggunaan berbagai media dan sumber belajar.

Gagne mengelompokan jenis media pembelajaran menjadi tujuh macam, yaitu benda untuk didemonstrasikan, komunikasi lisan, media cetak, gambar diam, gambar gerak, film bersuara, dan mesin belajar. Ketujuh kelompok media ini dikaitkan dengan kemampuan memenuhi fungsi menurut tingkat hirarki belajar yang dikembangkannya (Sadiman, dkk, 1986: 23).

Berdasarkan kondisi internal dan eksternal ini, Gagne menjelaskan bagaimana proses belajar itu terjadi. Model proses belajar yang dikembangkan Gagne didasarkan pada teori pemrosesan informasi, yaitu sebagai berikut:

1. Rangsangan yang diterima panca indra akan disalurkan ke pusat syaraf dan diproses sebagai informasi.

2. Informasi dipilih secara selektif, ada yang dibuang, ada yang disimpan dalam memori jangka pendek, dan ada yang disimpan dalam memori jangka panjang.

3. Memori-memori ini tercampur dengan memori yang telah ada sebelumnya, dan dapat diungkap kembali setelah dilakukan pengolahan.

Hasil penelitian Gagne tentang faktor-faktor yang kompleks pada proses belajar manusia menemukan teori pembelajaran yang efektif.
Analisanya dimulai dari identifikasi konsep hirarki belajar (learning hierarchies) yaitu uruturutan kemampuan yang harus dikuasai oleh peserta didik agar dapat mempelajari hal-hal yang lebih sulit atau lebih kompleks.

Misalnya satu standar kompetensi diajarkan mandahului standar kompetensi lainnya. Pada dasarnya, pengetahuan yang lebih sederhana harus dikuasai peserta didik terlebih dahulu dengan baik agar ia dapat dengan mudah mempelajari pengetahuan yang lebih rumit (komplek). Pertanyaan yang sering muncul adalah mengapa suatu standar kompetensi harus diajarkan mendahului standar kompetensi lainnya? Atas dasar apa penentuan itu? Apakah hanya didasarkan pada kata hati para guru dan pakar saja? Untuk menjawab pertanyaan tersebut, Gagne memberikan alasan pemecahan dan pengurutan materi pembelajaran dengan selalu menanyakan pertanyaan ini: "Pengetahuan apa yang lebih dahulu harus dikuasai peserta didik agar ia berhasil".

Implikasi konsep hirarki belajar dalam pembelajaran adalah perlunya melakukan analisis instruksional yaitu proses menjabarkan perilaku umum mendasi perilaku khusus yang tersusun secara logis dan sistematis. Dari susunan ini akan kelihatan kedudukan atau susunan perilaku khusus mana yang dilakukan lebih dahulu dari perilaku yang lain karena kedudukannya sebagai perilaku prasyarat, perilaku yang menurut urutan gerak fisik berlangsung lebih dahulu, perilaku yang menurut proses psikologis muncul lebih dahulu atau secara kronologis terjadi lebih awal. Dengan melakukan analisis instruksional akan tergambar susunan perilaku khusus dari yang paling awal atau sederhana sampai dengan yang paling akhir atau komplek (Suparman, 2004:99).

Misalnya dalam belajar Matematika, Gagne mengemukakan delapan tipe belajar yang dilakukan secara prosedural atau hirarkis. Kedelapan tipe belajar tersebut, yaitu: (1) belajar sinyal (signal learning), (2) belajar stimulus respon (stimulus response learning), (3) belajar merangkai tingkah laku (behavior chaining learning), (4) belajar asosiasi verbal 
(verval chaining learning), (5) belajar diskriminasi (discrimination learning), (6) belajar konsep (concept learning), (7) belajar aturan atau kaídah (rule learning), dan (8) belajar memecahkan masalah (problem solving learning). Hirarki belajar empat tipe pertama disebut sebagai tipe belajar sederhana (simple type of learning), sedangkan empat tipe terakhir disebut tipe belajar hipotetik deduktif (deductive hypothetic learning) (Hamzah B. Uno, 2007:131).

Kedelapan tipe belajar ini disusun berdasarkan pada hasil belajar yang diperoleh, dan bukan proses belajar yang dilalui peserta didik untuk sampai pada hasil itu. Selain itu, Gagne mencoba untuk menempatkan kedelapan tipe belajar itu dalam suatu urutan hirarkis, yaitu tipe belajar yang satu menjadi dasar atau landasan tipe belajar berikutnya. Artinya tipe belajar yang satu harus dikuasai terlebih dahulu, sebelum peserta didik mampu menguasai tipe belajar berikutnya. Dengan demikian peserta didik

Tabel 3. Bagan delatan tipe belajar (Winkel, 2005:102-103).

\begin{tabular}{|c|c|c|c|}
\hline No. & Tipe belajar & Hasil belajar & Contoh prestasi \\
\hline 1 & $\begin{array}{l}\text { Belajar sinyal } \\
\text { (signal learning) }\end{array}$ & $\begin{array}{l}\text { Memberikan reaksi pada } \\
\text { perangsang (S-R) }\end{array}$ & $\begin{array}{l}\text { Guru sejarah yang galak ditakuti } \\
\text { siswa- siswa tidak senang pada } \\
\text { sejarah. }\end{array}$ \\
\hline 2. & $\begin{array}{l}\text { Belajar stimulus respon } \\
\text { (stimulus response learning) }\end{array}$ & $\begin{array}{l}\text { Memberikan reaksi pada } \\
\text { perangsang (S- R) }\end{array}$ & $\begin{array}{l}\text { Guru memuji tindakan siswa - } \\
\text { cenderung siswa mengulang. }\end{array}$ \\
\hline 3 & $\begin{array}{l}\text { Belajar merangkai tingkah } \\
\text { laku (behavior chaining } \\
\text { learning) }\end{array}$ & $\begin{array}{l}\text { Menghubungkan gerakan yang satu } \\
\text { dengan yang lain }\end{array}$ & $\begin{array}{l}\text { Membuka pintu mobil-duduk-kontrol } \\
\text { persenelling-menghi-dupkan mesin- } \\
\text { mene-kan kopling-pasang } \\
\text { perseneling1-meng-injak gas }\end{array}$ \\
\hline 4 & $\begin{array}{l}\text { Belajar asosiasi verbal } \\
\text { (verbal chaining learning) }\end{array}$ & $\begin{array}{l}\text { Memberikan reaksi verbal pada } \\
\text { stimulus-/perangsang. }\end{array}$ & Nomor teleponmu? -(021) 617812 \\
\hline 5 & $\begin{array}{l}\text { Belajar diskriminasi } \\
\text { discrimination learning) }\end{array}$ & $\begin{array}{l}\text { Memberikan reaksi yang berbeda } \\
\text { pada stimulus-stimulus yang } \\
\text { mempunyai kesamaan. }\end{array}$ & $\begin{array}{l}\text { Menyebutkan merek mobil-mobil } \\
\text { yang lewat di jalan }\end{array}$ \\
\hline 6. & $\begin{array}{l}\text { Belajar konsep (concept } \\
\text { learning) }\end{array}$ & $\begin{array}{l}\text { Menempatkan obyek-obyek dalam } \\
\text { kelompok tertentu }\end{array}$ & $\begin{array}{l}\text { Manusia, ikan paus, kera, anjing } \\
\text { adalah mahkluk menyusui. }\end{array}$ \\
\hline 7. & $\begin{array}{l}\text { Belajar kaídah } \\
\text { (rule learning) }\end{array}$ & Menghubungkan beberapa konsep. & $\begin{array}{l}\text { Benda yang bulat berguling pada alas } \\
\text { yang miring. }\end{array}$ \\
\hline 8. & $\begin{array}{l}\text { Belajar memecahkan } \\
\text { masalah (problem solving) }\end{array}$ & $\begin{array}{l}\text { Mengembangkan beberapa kaídah } \\
\text { menjadi prinsip pemecahan } \\
\text { masalah. }\end{array}$ & $\begin{array}{l}\text { Menemukan cara memperoleh energi } \\
\text { dari tenaga atom, tanpa mencemarkan } \\
\text { lingkungan hidup. }\end{array}$ \\
\hline
\end{tabular}


yang tidak menguasai tipe belajar yang mendahului, akan mengalami kesulitan dalam menguasai tepe belajar yang lebih atas.

Selanjutnya, Gagne menambahkan empat tipe belajar pertama (no. 1 s.d 4) kurang relevan untuk belajar di sekolah, sedangkan empat tipe kedua (no. 5 s.d 8) lebih menonjolkan pada belajar bidang kognitif yang memang diutamakan di sekolah (Winkel, 2005:100-101). Untuk lebih jelasnya, kedelapan tipe belajar ini disajikan dalam tabel berikut!.

Dengan demikian, ada beberapa prinsip pembelajaran dari teori Gagne, yaitu antara lain berkaitan dengan: (a) perhatian dan motivasi belajar peserta didik, (b) keaktifan belajar dan keterlibatan langsung/ pengalaman dalam belajar, (c) pengulangan belajar, (d) tantangan semangat belajar, (e) pemberian balikan dan penguatan belajar, serta (f) adanya perbedaan individual dalam perilaku belajar. Selain itu, yang terpenting menurut Gagne adalah penciptaan kondisi belajar, termasuk lingkungan belajar, khususnya kondisi yang berbasis media, yaitu meliputi jenis penyajian yang disampaikan kepada peserta didik dengan penjadwalan, pengurutan dan pengorganisasiannya (Gagne, 1990:3). Semua ini akan berpengaruh atau berimplikasi pada pengembangan Pusat Sumber Belajar (PSB) atau Learning Resource Center (LRC).

Selain itu, teori pembelajaran Gagne menekankan pada prosedur pembelajaran yang telah terbukti berhasil meningkatkan kualitas pembelajaran yaitu:

a. Belajar merupakan suatu kumpulan proses yang bersifat individu, yang merubah stimuli yang datang dari lingkungan seseorang ke dalam sejumlah informasi yang selanjutnya dapat menyebabkan adanya hasil belajar dalam bentuk ingatan jangka panjang. Hasilhasil belajar ini memberikan kemampuan melakukan berbagai penampilan;

b. Kemampuan yang merupakan hasil belajar ini dapat dikategorikan bersifat praktis dan teoritis.

c. Peristiwa-peristiwa di dalam pembelajaran yang mempengaruhi proses belajar dapat dikelompokkan ke dalam kategori umum, tanpa memperhatikan hasil belajar yang diharapkan. Namun tiap-tiap hasil belajar memerlukan adanya peristiwa-peristiwa khusus untuk dapat terbentuk (Gagne, 1985).

Dari uraian di atas tampak bahwa teori pembelajaran merupakan suatu kumpulan prinsip yang terintegrasi dan memberikan preskripsi (petunjuk) untuk mengatur kondisi agar peserta didik mudah belajar dalam mencapai tujuan pembelajaran. Prinsipprinsip pembelajaran dapat diterapkan dalam pembelajaran tatap muka di kelas maupun pembelajaran terbuka/jarak jauh, pembelajaran terprogram, dan lain lain. Teori pembelajaran juga memberi arahan dalam memilih metode pembelajaran yang paling tepat untuk suatu pembelajaran tertentu.

\section{IMPLIKASI TEORI BELAJAR ROBERT M. GAGNE PADA PENGEMBANGAN PSB}

Kesempatan untuk belajar harus dapat dinikmati oleh setiap anggota masyarakat, dalam rangka meningkatkan pengetahuan, keterampilan dan sikap sesuai dengan kebutuhan dan tuntutan zaman. Oleh karena itu layanan pendidikan harus dapat menjangkau seluas mungkin seluruh lapisan masyarakat. Masyarakat seharusnya dapat belajar secara mudah kapan saja, di mana saja, dari siapa saja, dan mengenai apa saja.

Belajar tidak hanya dilakukan oleh dan untuk individu, melainkan oleh dan untuk kelompok, bahkan oleh organisasi secara keseluruhan. Belajar itu ada di mana saja, kapan saja dan pada siapa saja, mengenai apa saja, dengan cara dan sumber apa saja yang sesuai dengan kondisi dan keperluan atau kebutuhan (Miarso, 2004:193-194).

Konsep belajar sebagai suatu upaya atau proses perubahan tingkah laku seseorang sebagai akibat interaksi individu yang bersangkutan dengan berbagai sumber belajar yang ada di sekitarnya. Salah satu tanda seseorang telah belajar adalah adanya perubahan tingkah laku dalam dirinya. Perubahan tingkah laku tersebut meliputi perubahan pengetahuan (kognitif), 
keterampilan (psikomotor), dan nilai sikap (afektif). Dengan demikian, belajar adalah proses orang memperoleh berbagai kecakapan, keterampilan, dan sikap (Gredler, 1994:1). Proses belajar pada hakekatnya terjadi dalam diri individu yang bersangkutan, walaupun prosesnya berlangsung dalam kelompok, bersama orang lain.

Belajar merupakan suatu proses pribadi yang tidak harus dan atau merupakan akibat kegiatan mengajar. Guru melakukan kegiatan mengajar tidak selalu diikuti terjadinya kegiatan belajar pada peserta didik. Sebaliknya, peserta didik dapat melakukan kegiatan belajar tanpa harus ada guru yang mengajar. Namun dalam kegiatan belajar peserta didik ini ada kegiatan membelajarkan, yaitu misalnya yang dilakukan oleh penulis buku bahan belajar, atau pengembang paket belajar, dan sebagainya (Miarso, 12004: 553554). Dengan demikian, belajar yang sesungguhnya (the real learning) perlu adanya sumber belajar.

Konsep belajar adalah mengingat, .Belajar adalah memahami. Belajar adalah menerapkan (melakukan, keterampilan, praktek). Belajar adalah pengembangan diri. Aspek yang perlu dikembangkan dalam belajar adalah semua aspek yang ada pada manusia. Sedangkan menurut Howard Gardner (1983), manusia mempunyai delapan kemampuan jamak (8 ways of knowing multiple intelligencis) yaitu; (1) verbal (linguistic), (2) logical (mathematical), (3) visual (spatial), (4) intrapersonal, (5) interpersonal, (6) musical (rhythmic), (7) bodily (kinesthetic), dan (8) naturalist. Selain itu juga ada kecerdasan speritual dan aksential. Setiap individu memiliki kedelapan kecerdasan tersebut, tetapi dalam tingkat yang berbeda-beda. Sehingga masingmasing perlu dikembangkan.

Pembelajaran adalah usaha untuk membuat peserta didik belajar atau suatu upaya untuk menciptakan kondisi agar terjadi kegiatan belajar. Dengan kata lain, pembelajaran adalah usaha-usaha yang terencana dalam memanipulasi sumber-sumber belajar agar terjadi proses belajar dalam diri peserta didik (Sadiman, dkk, 1986:7). Pembelajaran disebut juga kegiatan pembelajaran (instruksional) adalah usaha mengelola lingkungan dengan sengaja agar peserta didik membentuk diri secara positif dalam kondisi tertentu (Miarso, 2004: 528). Dengan demikian, inti dari pembelajaran adalah segala upaya yang dilakukan oleh pendidik agar terjadi proses belajar pada diri peserta didik. Kegiatan pembelajaran tidak akan berarti jika tidak menghasilkan kegiatan belajar pada para peserta didiknya.

UU No. 20 tahun 2003 tentang Sistem Pendidikan NAsional (Sisdiknas) pasal 1 ayat 20, mengemukakan bahwa pembelajaran adalah proses interaksi peserta didik dengan pendidik dan sumber belajar pada suatu lingkungan belajar (Depdiknas, 2003:7). Kegiatan pembelajaran dirancang untuk memberikan pengalaman belajar yang melibatkan proses mental dan fisik melalui interaksi antar peserta didik, peserta didik dengan guru, lingkungan, dan sumber belajar lainnya dalam rangka pencapaian kompetensi dasar (BSNP, 2006:16). Pengalaman belajar yang dimaksud dapat terwujud melalui penggunaan pendekatan pembelajaran yang bervariasi dan berpusat pada peserta didik. Pengalaman belajar memuat kecakapan hidup yang perlu dikuasai peserta didik.

Oleh karena itu, perlu diciptakan proses pembelajaran yang menantang dan merangsang otak (kognitif), menyentuh dan menggerakkan perasaan (afektif), dan mendorong peserta didik untuk melakukan kegiatan (motorik) serta bila memungkinkan peserta didik mempraktekkan pengetahuan dan keterampilan dalam suasana konkrit (Soedijarto, 2000:40,84). Kegiatan pembelajaran ini akan menjadi bermakna bagi peserta didik jika dilakukan dalam lingkungan yang nyaman dan memberikan rasa aman bagi peserta didik.

Proses pembelajaran pada setiap satuan pendidikan supaya diselenggarakan secara interaktif, inspiratif, menyenangkan, menantang, memotivasi peserta didik untuk berpartisipasi aktif, serta memberikan ruang yang cukup bagi prakarsa, kreativitas, dan kemandirian sesuai dengan bakat, minat, dan perkembangan fisik serta psikologis peserta didik (Pasal 19, PP No.19 th 2005 tentang Standar Nasional Pendidikan).

Dalam proses pembelajaran, seorang pendidik dituntut untuk dapat membangkitkan motivasi belajar pada diri peserta didik. Seseorang tidak akan pernah belajar jika tidak termotivasi untuk itu. Orang tidak dapat 
dipaksa untuk belajar. Artinya harus memiliki keinginan untuk belajar. Maksudnya peserta didik harus termotivasi untuk melibatkan diri dalam proses belajar. Motivasi dan usaha mempengaruhi belajar dan unjuk kerja peserta didik. Oleh karena itu, motivasilah peserta didik dengan tugas-tugas riil dalam kehidupan nyata sehari-hari dan kaitkan tugas dengan pengalaman pribadinya. Kemudian, doronglah peserta didik untuk memahami kaitan antara usaha dan hasil yang dicapai. Untuk mewujudkan model pembelajaran ini diperlukan berbagai sumber belajar.

Proses belajar bersifat individual dan kontekstual. Artinya, proses belajar terjadi dalam diri individu sesuai dengan perkembangannya dan lingkungannya. Peserta didik seharusnya tidak hanya belajar dari guru atau pendidik saja, tetapi dapat pula belajar dengan berbagai sumber belajar yang tersedia di lingkungannya. Sumber belajar dapat berupa pesan (massage), orang (people), bahan (materials/software), alat (devices/hardware), teknik (technique), dan lingkungan (setting).

1. Pesan adalah informasi pembelajaran yang akan disampaikan, dapat berupa ide, fakta, ajaran, nilai dan data. Dalam sistem persekolahan, pesan ini berupa seluruh mata pelajaran yang disampaikan kepada peserta didik.

2. Orang adalah manusia yang berperan sebagai pencari, penyimpan, pengolah, dan penyaji pesan. Contohnya guru, dosen, tutor, pustakawan, Iaboran, instruktur, widyaiswara, pelatih olah raga, tenaga ahli, produser, peneliti dan masih banyak lagi, bahkan termasuk peserta didik itu sendiri.

3. Bahan adalah perangkat lunak (software) yang mengandung pesan-pesan pembelajaran yang biasanya disajikan melalui peralatan tertentu ataupun oleh dirinya sendiri. Contohnya, buku teks, modul, transparansi (OHT), kaset program audio, kaset program video, program slide suara, programmed instruction, CAI (pembelajaran berbasisi komputer), film dan lain-lain.

4. Alat adalah perangkat keras (hardware) yang digunakan untuk menyajikan pesan yang tersimpan dalam bahan. Contohnya,
OHP, proyektor slide, tape recorder, video/ CD player, komputer, proyektor film, dan lain-lain.

5. Teknik adalah prosedur atau langkahlangkah tertentu yang disiapkan dalam menggunakan bahan, alat, lingkungan dan orang untuk menyampaikan pesan. Misalnya demonstrasi, diskusi, praktikum, pembelajaran mandiri, sistem pendidikan terbuka/jarak jauh, tutorial tatap muka, dan sebagainya.

6. Latar/lingkungan adalah situasi di sekitar terjadinya proses pembelajaran di mana peserta didik menerima pesan pembelajaran. Lingkungan dibedakan menjadi dua macam, yaitu lingkungan fisik dan lingkungan non fisik. Lingkungan fisik contohnya, gedung sekolah, perpustakaan, laboratorium, aula, bengkel, dan lain-lain. Sedangkan lingkungan non fisik contohnya, tata ruang belajar, ventilasi udara, cuaca, suasana lingkungan belajar dan lain-lain.

Sedangkan bahan dan alat yang sering disebut software dan hardware merupakan media pembelajaran (Sadiman, dkk, 1986:67). Dalam perkembangannya, bahan belajar itu sendiri ada yang bersifat on line, misalnya bahan belajar yang ditaruh di internet. Selain itu, ada pula yang bersifat off line, misalnya buku pelajaran, program audio, program video, VCD, modul, program multimedia, dan sebagainya. Dengan demikian media pembelajaran bisa dipahami sebagai media yang digunakan dalam proses dan tujuan pembelajaran.

Pada hakekatnya, alam semesta ini merupakan sumber belajar bagi manusia sepanjang masa. Jadi, konsep sumber belajar memiliki makna yang sangat luas meliputi segala yang ada di jagad raya ini. Menurut Assosiasi Teknologi Komunikasi Pendidikan (AECT), sumber belajar meliputi semua sumber (baik berupa data, orang atau benda) yang dapat digunakan untuk memberi fasilitas (kemudahan) belajar bagi peserta didik (Miarso, 1986).

Menurut Donal P. Ely (1978: 3), sumber belajar adalah data, orang, dan atau sesuatu yang memungkinkan peserta didik melakukan 
belajar. Sumber belajar meliputi semua sumber yang berkenaan dengan data, manusia, barang-barang yang memungkinkan dapat digunakan secara terpisah atau kombinasi, yang oleh peserta didik biasanya digunakan secara optimal untuk memberikan fasilitas dalam kegiatan belajar (Silber Kenneth, 1977: 8). Kemudian, sumber belajar disebut sebagai satu set bahan atau situasi yang dengan sengaja diciptakan untuk menunjang peserta didik belajar mandiri (Percival dan Ellington, 1988: 124). Dengan demikian, sumber belajar yang dimanfaatkan dalam pendidikan adalah suatu sistem yang terdiri dari sekumpulan bahan atau situasi yang diciptakan dengan sengaja dan dibuat agar memungkinkan peserta didik belajar secara individual. Sumber belajar inilah yang sering disebut dengan media pembelajaran.

Dalam pemilihan sumber belajar, ada beberapa kriteria, yaitu: (a) harus dapat tersedia dengan cepat, (b) harus memungkinkan peserta didik untuk memacu diri sendiri, dan (c) harus bersifat individual, dapat memenuhi berbagai kebutuhan peserta didik dalam belajar mandiri (Percival dan Ellington, 1988: 125). Selain itu, sumber belajar adalah segala macam sumber yang ada di luar diri seseorang (peserta didik) dan yang memungkinkan (memudahkan) terjadinya proses belajar. Oleh karena itu dalam pemilihan sumber belajar yang baik, perlu memperhatikan beberapa kriteria, yaitu: ekonomis, praktis dan sederhana, mudah diperoleh, bersifat fleksibel (luwes), dan komponen-komponennya sesuai dengan tujuan pembelajaran (Ahmad Rohani, 1997:112).

Ditinjau dari tipe atau asal-usulnya, sumber belajar dapat dibedakan menjadi dua jenis, yaitu:

a. Sumber belajar yang dirancang (learning resources by design), yaitu sumber belajar yang secara khusus atau sengaja dirancang atau dikembangkan untuk mencapai tujuan pembelajaran tertentu. Contohnya, buku pelajaran, modul, program VCD pembelajaran, program audio pembelajaran, transparansi, CAI (Computer Asisted Instruction), programmed instruction, dan lain-lain. b. Sumber belajar yang sudah tersedia dan tinggal dimanfaatkan (learning resources by utilization), yaitu sumber belajar yang secara tidak khusus dirancang atau dikembangkan untuk keperluan pembelajaran, tetapi dapat dipilih dan dimanfaatkan untuk keperluan pembelajaran. Contohnya: surat kabar, siaran televisi, pasar, sawah, waduk, pabrik, museum, kebun binatang, pabrik, terminal, pejabat pemerintah, tenaga ahli, pemuka agama, olahragawan, dan lainlain.

Konsepsi pembelajaran ini menuntut peserta didik aktif, responsif, dan aktif dalam mencari, memilih, menemukan, menganalisis, menyimpulkan, dan melaporkan hasil belajarnya. Sistem belajar semacam ini hanya dapat terlaksana dengan baik apabila tersedia sumber-sumber belajar yang memadai dan dikelola oleh suatu lembaga yaitu Pusat Sumber Belajar (PSB).

Gerakan pertumbuhan PSB secara historis merupakan suatu kemajuan yang bersifat graduil tetapi direncanakan, dari bentuknya yang pertama yaitu perpustakaan yang memberikan penekanan pada media cetak. Dalam melaksanakan kegiatannya, perpustakaan mereaksi atas permintaanpermintaan dan memberikan layanan kepada para konsumen yang bervariasi secara luas. Selain itu, karena adanya pertumbuhan berikutnya berupa pengakuan akan semakin dibutuhkannya pelayanan dan kegiatankegiatan belajar non-tradisional, misalnya pembelajaran dengan modul, penggunaan metoda simulasi dan permainan, belajar sendiri dan bebas, dsb. Dengan demikian, salah satu alasan yang mendorong timbulnya PSB adalah adanya pengembangan sistem instruksional yang akan dapat meningkatkan efektivitas dan efisiensi kegiatan pembelajaran.

Pengembangan sistem instruksional adalah suatu proses yang sistematis dan terusmenerus yang akan membantu para pendidik dalam mengembangkan pengalamanpengalaman belajar yang paling efektif dan efisien bagi peserta didik. Di dalam proses ini dapat diidentifikasi berbagai variasi pilihan 
kegiatan pembelajaran, di mana pilihan ditentukan berdasarkan tujuan yang ingin dicapai.

Salah satu model pengembangan instruksional (Instructional System Design) (Gagne, 1979) yaitu: Tingkat sistem: (1) analisis kebutuhan, tujuan umum, dan prioritas, (2) analisis sumber, hambatan, dan alternatif sistem peluncuran, (3) penentuan lingkup dan urutan kurikulum dan mata pelajaran, desain sistem peluncuran. Tingkat mata pelajaran: (4) menentukan struktur mata pelajaran dan urutan, (5) analisis tujuan mata pelajaran. Tingkat mata sajian/topik: (6) pendefinisian tujuan penampilan, (7) mempersiapkan rencana mata pelajaran, (8) mengembangkan, memilih media dan bahan belajar, dan (9) menilai/mengukur penampilan peserta didik (Suparman, 2004: 62). Di sinilah letak hubungan yang penting antara PSB dengan Pengembangan Sistem Instruksional (instructional development).

Segala sumber dan bahan pembelajaran, segala macam peralatan audio visual, segala macam tipe personnel yang ada di dalam PSB, semuanya itu dimaksudkan untuk membantu mewujudkan pengembangan sistem instruksional untuk meningkatkan efektivitas dan efisiensi proses pembelajaran.

Hakekat dari PSB adalah terpusat kepada kepentingan belajar peserta didik. Dalam rangka mengembangkan kepribadiannya dan untuk mencapai tujuan-tujuan pembelajaran tertentu diperlukan lingkungan belajar tertentu, misalnya interaksi belajar dalam kelompok kecil, belajar mandiri, belajar bebas, dan sebagainya.

Untuk dapat memilih macam lingkungan belajar yang tepat untuk mencapai tujuan pembelajaran tertentu, dan bahan tertentu yang kiranya sangat relevan, maka secara mutlak diperlukan adanya pengembangan sistem instruksional yang dilaksanakan secara sistematis dan sistemik. Sebaliknya, pengembangan sistem instruksional ini dapat dilaksanakan dengan baik bila ada perpustakaan bahan-bahan pembelajaran dan pelayanan peralatan yang relevan.
Sedangkan menurut Irving R. Merril dan Harold A. Drob, PSB adalah: "an organized activity consisting of a director, staff, and equipment housed in one or more specialized facilities for the production, procurement, and presentation of instructional material and the provision of developmental and planning services related to the curriculum and teaching on a general university campus" (PSB dipandang sebagai suatu kegiatan yang terorganisasi yang terdiri dari Direktur PSB, staf, peralatan dan bahan-bahan pembelajaran yang ditempatkan dalam suatu lokasi yang mempunyai satu atau lebih fasilitas khusus untuk perencanaan, pembuatan, penyajian, pengembangan dan pelayanan perencanaan yang berhubungan dengan kurikulum dan pembelajaran pada suatu satuan pendidikan) (Merril dan Drob, 1977:3)..

Dengan demikian, PSB merupakan wahana yang memberikan fasilitas atau kemudahan pada proses pembelajaran, di mana berbagai jenis sumber belajar dikembangkan, dikelola, dan dimanfaatkan untuk membantu meningkatkan efektivitas dan efisiensi kegiatan pembelajaran (Sukorini, 2007:96).

Perkembangan PSB mengalami beberapa tahapan, yaitu: tahap pertama, pemanfaatan dan pengembangan sumber belajar tidak dikelola dan diorganisir secara formal oleh suatu lembaga, melainkan hanya oleh orang perorang saja. Tahap kedua, dimulai dengan istilah perpustakaan yang mengoleksi sumber belajar berupa bahan cetak. Tahap ketiga, sesuai perkembangan peranan media audio visual dalam bidang pendidikan, timbulah perpustakaan yang dilengkapi dengan pelayanan audio visual. Pada tahap keempat, perpustakaan semacam ini kemudian dilengkapi dengan ruang belajar non tradisional sehingga timbullah PSB yang terdiri dari perpustakaan, ruang belajar tradisional, dan pelayanan audio visual. Tahap kelima, di samping PSB terdiri dari perpustakaan, ruang belajar tradisional dan pelayanan audio visual juga ditambah dengan komponen kegiatan yang sangat penting, yaitu pengembangan sistem pembelajaran (Gary T. Peterson, 1975). 
Dengan tahap perkembangan tersebut, PSB memberikan penekanan pada belajar peserta didik, baik sebagai hasil yang dicapai maupun proses yang dilalui untuk mencapai hasil belajar yang optimal.

\section{Tujuan PSB}

a. Tujuan Umum

PSB bertujuan untuk meningkatkan efektivitas dan efisiensi kegiatan dan proses pembelajaran melalui pengembangan sistem instruksional. Hal ini dilaksanakan dengan menyediakan berbagai macam pilihan untuk menyokong kegiatan kelas tradisional dan untuk mendorong penggunaan cara-cara belajar yang baru (non-tradisional) yang paling sesuai untuk mencapai tujuan semua program pendidikan dan kewajibankewajiban institusional yang direncanakan lainnya.

Sedangkan misi utama dari PSB adalah pengembangan sistem instruksional yang merupakan sarana utama untuk meningkatkan efektivitas dan efisiensi kegiatan pembelajaran. Segala fungsi dan kegiatan yang dilaksanakan PSB, termasuk pengadaan dan pelayanan perpustakaan bahan pengajaran, dimaksudkan untuk mencapai berhasilnya pelaksanaan misi tersebut.

\section{b. Tujuan Khusus}

1) Menyediakan berbagai macam pilihan komunikasi untuk menyokong kegiatan kelas tradisional.

2) Mendorong penggunaan caracara belajar yang baru yang paling cocok untuk mencapai tujuan program akademis dan kewajiban-kewajiban institusional lainnya.

3) Memberikan Iayanan dalam perencanaan, produksi, operasional, dan tindakan lanjutan untuk pengembangan sistem instruksional.

4) Melaksanakan latihan kepada para instruktur/staff tenaga pengajar mengenai pengembangan sistem instruksional dan integrasi teknologi dalam proses pembelajaran.

5) Memajukan penelitian yang perlu tentang penggunaan media pendidikan.

6) Menyebarkan informasi yang akan membantu memajukan penggunaan berbagai macam sumber belajar dengan lebih efektif dan efisien.

7) Menyediakan layanan produksi bahan belajar.

8) Memberikan konsultasi untuk modifikasi dan design fasilitas.

9) Membantu mengembangkan standar penggunaan sumbersumber belajar.

10) Menyediakan Iayanan pemeliharaan atas berbagai macam peralatan media.

11) Membantu dalam pemilihan dan pengadaan bahan-bahan media kelas dan peralatannya.

12) Menyediakan pelayanan penilaian untuk membantu menentukan efektivitas berbagai cara pengajaran.

\section{Fungsi PSB}

Berdasarkan tujuan umum dan tujuan khusus yang sudah diuraikan di atas, PSB mempunyai fungsi dan kegiatan sebagai berikut:

a. Fungsi Pengembangan Sistem Instruksional

Fungsi ini menolong dinas atau bagian dan staff tenaga pengajar secara individual di dalam membuat rancangan (design) dan pemilihan options (pilihan) yang akan meningkatkan efektivitas dan efisiensi proses pembelajaran. Hal ini meliputi: perencanaan kurikulum, identifikasi pilihan instruksional, seleksi peralatan dan bahan, menghitung perkiraan biaya, lokakarya staff tenaga pengajar tentang pengembangan sistem instruksional, perencanaan program, prosedur evaluasi, dan revisi 
program.

\section{b. Fungsi Pelayanan Media}

Fungsi ini berhubungan dengan pelaksanaan memprogram media dan pelayanan dukungan (support) yang dibutuhkan oleh staff pengajar dan peserta didik. Hal ini meliputi: sistem media untuk kelompok besar, sistem media untuk kelas standard, fasilitas dan program belajar mandiri, pelayanan perpustakaan media/ bahan pembelajaran, pelayanan pemiliharaan dan penyampaian, pelayanan pembelian bahan-bahan dan peralatan.

\section{c. Fungsi Produksi}

Fungsi ini berhubungan dengan penyediaan materi atau bahan-bahan instruksional yang tidak dapat diperoleh melalui sumber-sumber yang diperdagangkan. Hal ini meliputi: penyiapan karya seni original (original art work) untuk tujuan instruksional, produksi OHP transparencies, produksi fotografi original (slides, prints/cetak, dII), pelayanan membuat kopi fotografik, memprogram, mengedit dan memperbanyak pita suara, memprogram, memelihara dan mengembangkan sistem

\section{d. Fungsi Administrasi}

Fungsi ini berhubungan dengan caracara yang mengarah pada pencapaian tujuan dan prioritas program dapat tercapai. Hal ini berarti bahwa fungsi ini berhubungan dengan semua segi program yang akan dilaksanakan dan akan melibatkan kepada semua staff dan pemakai di dalam cara-cara yang cocok. Hal ini meliputi beberapa kegiatan sebagai berikut: mengawasi media personel, mengembangkan koleksi media untuk program pembelajaran, mengembangkan spesifikasi pendidikan untuk fasilitas baru, mengembangkan sistem penyampaian, memelihara kelangsungan pelayanan produksi bahan pengajaran, menyediakan pelayanan untuk pemeliharaan bahan, peralatan dan fasilitas

\section{e. Fungsi Pelatihan}

Fungsi ini berhubungan dengan upaya untuk meningkatkan kemampuan sumber daya manusia (SDM), baik untuk pengelola PSB maupun masyarakat pengguna.

\section{Manfaat Pengembangan PSB}

Pengembangan PSB pada suatu satuan pendidikan, memberikan manfaat yaitu antara lain untuk: (a) memperluas dan meningkatkan kesempatan belajar; (b) melayani kebutuhan perkembangan informasi bagi masyarakat; (c) mengembangkan kreativitas dan produktivitas tenaga pendidik dan kependidikan; (d) meningkatkan efektivitas dan efisiensi proses pembelajaran, baik secara individu maupun kelompok; (e) menyediakan berbagai macam pilihan komunikasi untuk menunjang kegiatan kelas tradisional; (f) mendorong cara-cara belajar baru yang paling cocok untuk mencapai tujuan pembelajaran; (g) memberikan pelayanan dalam perencanaan, produksi, operasional, dan tindakan lanjutan untuk pengembangan sistem pembelajaran; (h) melaksanakan latihan bagi para tenaga pengajar mengenai pengembangan sistem pembelajaran dan pemanfaatan Teknologi Informasi dan Komunikasi (TIK) untuk pembelajaran; (i) memajukan usaha penelitian yang perlu tentang penggunaan media pembelajaran; (j) memberikan alasan dan menfasilitasi dengan sumber belajar di luar PSB; (k) menyebarkan berbagai informasi pembelajaran yang akan membantu memajukan penggunaan berbagai macam sumber belajar dengan lebih efektif dan efisien; (I) menyediakan pelayanan produksi bahan pembelajaran; (m) memberikan konsultasi untuk modifikasi dan desain fasilitas sumber belajar; (n) membantu mengembangkan standar penggunaan berbagai sumber belajar; (o) menyediakan pelayanan 
pemeliharaan atas berbagai macam peralatan media; $(p)$ membantu dalam pemilihan dan pengadaan bahan-bahan media dan peralatannya; (q) menyediakan pelayanan evaluasi untuk membantu menentukan efektivitas berbagai cara/metode pembelajaran.

\section{KESIMPULAN DAN SARAN-SARAN}

Sebagai penutup berikut ini beberapa kesimpulan yang perlu diperhatikan dalam pengembangan PSB, yaitu:

a. Teori belajar Robert. M. Gagne ini membantu kita untuk memahami proses belajar yang terjadi di dalam diri peserta didik, mengerti kondisi-kondisi dan faktorfaktor yang dapat mempengaruhi, memperlancar atau menghambat proses belajar peserta didik sehingga dapat bertindak secara tepat.

b. Belajar merupakan seperangkat proses yang bersifat internal bagi setiap individu yang merupakan hasil transformasi rangsangan yang berasal dari peristiwa eksternal di lingkungan individu yang bersangkutan.

c. Menurut Gagne, ada lima kemampuan belajar, yaitu: (1) keterampilan intelektual,

(2) strategi kognitif, (3) informasi verbal,

(4) keterampilan motorik, dan (5) sikap.

d. Hirarki belajar (learning hierarchies) adalah urut-urutan kemampuan yang harus dikuasai oleh peserta didik agar dapat mempelajari hal-hal yang lebih sulit atau lebih kompleks.

e. Ada delapan tipe belajar Gagne yaitu: (1) belajar sinyal (signal learning), (2) belajar stimulus respon (stimulus response learning), (3) belajar merangkai tingkah laku (behavior chaining learning), (4) belajar asosiasi verbal (verval chaining learning), (5) belajar diskriminasi (discrimination learning), (6) belajar konsep (concept learning), (7) belajar kaídah (rule learning), dan (8) belajar memecahkan masalah (problem solving learning)

f. Sumber belajar meliputi semua sumber (baik berupa data, orang maupun benda) yang dapat digunakan untuk memberi fasilitas (kemudahan) dan menunjang belajar bagi peserta didik.

g. Segala sumber dan bahan pembelajaran, segala macam peralatan audio visual, segala macam tipe personnel yang ada di dalam PSB, semuanya itu dimaksudkan untuk membantu mewujudkan pengembangan sistem instruksional untuk meningkatkan efektivitas dan efisiensi proses pembelajaran.

h. Fungsi dan kegiatan PSB akan sangat tergantung pada tujuan pembelajaran, fasilitas, peralatan, media dan bahan belajar yang dimiliki, staf pengelola PSB yang bersangkutan. Tetapi yang pasti bahwa kelima fungsi tersebut akan selalu ada dalam setiap PSB sebagai suatu lembaga yang berusaha untuk meningkatkan kualitas proses pembelajaran.

Selain itu berdasarkan uraian dan kesimpulan di atas, dapat diberikan saran-saran sebagai berikut:

a. Dalam kegiatan pembelajaran tidak dapat dilakukan sembarangan, tetapi supaya menggunakan teori-teori dan prinsipprinsip belajar tertentu misalnya teori Robert. M. Gagne agar bisa bertindak secara tepat.

b. Teori belajar Robert M. Gagne ini supaya dijadikan acuan atau landasan dalam melakukan intervensi dengan mengembangkan PSB, sehingga dapat meningkatkan efektivitas dan efisiensi kegiatan dan proses pembelajaran melalui pengembangan sistem instruksional.

c. Proses pembelajaran pada setiap satuan pendidikan supaya diselenggarakan secara interaktif, inspiratif, menyenangkan, menantang, memotivasi peserta didik untuk berpartisipasi aktif, serta memberikan ruang yang cukup bagi prakarsa, kreativitas, dan kemandirian sesuai dengan bakat, minat, dan perkembangan fisik serta psikologis peserta didik.

d. Peserta didik supaya tidak hanya belajar dari guru atau pendidik saja, tetapi dapat belajar dengan berbagai sumber belajar berupa pesan (massage), orang (people), bahan (materials/software), alat (devices/ 
hardware), teknik (technique), dan lingkungan (setting) yang dikelola oleh suatu lembaga yaitu Pusat Sumber Belajar (PSB).

\section{DAFTAR PUSTAKA}

Bell Gredler, Margaret E, Belajar dan Pembelajaran, Terjemahan Munandir, Jakarta: Penerbit PT. Raja Grafindo Persada bekerjasama dengan PAU-UT, 1994.

Depdiknas, Undang-Undang Republik Indonesia Nomor 20 Tahun 2003 Tentang Sistem Pendidikan Nasional, Jakarta: Biro Hukum dan Organisasi Depdiknas, 2003.

Gagne, Robert M., The Conditions of Learning, New York: Holt, Rinehart and Winston, 1977.

Gagne, Robert M., The Cognitive Psychology of School Learning, Boston Toronto: Little, Brown and Company, 1985.

Merril, Irving R., Harold A. Drob, Criteria for Planning the Collage and University Learning Resource Center, Washington Dc,: Association for Educational Communication and Technology, 1977.

Miarso, Yusufhadi, Menyemai Benih Teknologi Pendidikan, Jakarta: Penerbit Prenada Media, 2004.

Mudjiono, Dimyati, Belajar dan Pembelajaran, Jakarta: Penerbit Kerjasama Pusat Perbukuan, Depdiknas dan PT. Rineka Cipta,
2002.

Peterson, Gary T., Conceptualizing the Learning Center, Washington Dc: Planning and Operating Media Centers, Association for Educational Communication and Technology, 1975.

Learning Resource Center, State Unuversity of New York, Collage of Art and Science, Oswego, New York.

Sadiman, Arief S.,Pengembangan Learning Resource Center, (makalah terbatas).

Sadiman, Arief S., R. Rahardjo, Anung Haryono, Hardjito, Media Pendidikan, Pengertian, Pengembangan dan Pemanfaatannya, Jakarta: Penerbit CV. Rajawali, 1986.

Soedijarto, Pendidikan Nasional, Sebagai Wahana Mencerdaskan Kehidupan Bangsa dan Membangun Peradaban Negara-Bangsa (Sebuah Usaha Memahami Makna UUD 1945, Jakarta: Penerbit CINAPS, 2000.

Suparman, M. Atwi, Desain Instruksional, Jakarta: Penerbitan Universitas Terbuka, 2004.

Suciati, Irawan, Prasetya, Teori Belajar dan Motivasi, Jakarta: Depdiknas, Ditjen PT. PAUUT, 2001.

Uno, Hamzah B., Model Pembelajaran Menciptakan Proses Belajar Mengajar yang Kreatif dan Efektif, Jakarta: Penerbit PT. Bumi Aksara, 2007.

Winlel, W.S., Psikologi Pengajaran (Cetakan Ketujuh), Yogyakarta: Penerbit Media Abadi, 2005. 